\title{
Texts of tourism branding as object of translation
}

\author{
V. A. Mityagina \\ Translation Studies Department \\ Volgograd State University \\ Volgograd, Russia \\ mityagina@volsu.ru \\ E. Yu. Novikova \\ Translation Studies Department \\ Volgograd State University \\ Volgograd, Russia \\ nov-elina@volsu.ru
}

\author{
T. Yu. Makhortova \\ Translation Studies Department \\ Volgograd State University \\ Volgograd, Russia \\ machortova@volsu.ru \\ I. D. Volkova \\ Translation Studies Department \\ Volgograd State University \\ Volgograd, Russia \\ machortova@volsu.ru
}

\begin{abstract}
The paper deals with the intercultural and translational aspects of tourism branding, which involve, first of all, studying the peculiarities of the creation and promotion of tourism territory's brand in a foreign communicative space. The analyzed examples from the website of Interkon Travel Service GmbH / Levitin Reisen company, one of the largest and most famous Russian-language tour operators in Germany, allow concluding that the nominations of the tourist brand in translated texts can be, on the one hand, simplified and reduced, and, on the other hand, expanded to a significant scale for potential tourists. These processes are conditioned by the pragmatics of communicative interactions in the tourism discourse, which determine the necessary degree of explicitation and the form of pointing out separate components of the semantic-pragmatic content of the brand. The authors also point out the further tasks for studying the specificity of tourism branding, such as identifying the pragmatic specificity of a foreign-language recipient of branding texts, finding the optimal technology for translating the tourism branding texts, linguistic and cultural adaptation of branding texts in the translation process, etc.
\end{abstract}

Key words - brand; translation; tourism; territorial branding; pragmatics.

\section{INTRODUCTION}

In the modern Russian economy, the tourism is one of the promising industries that ensures the raise of living standards and economic growth as it makes a significant contribution to attracting foreign investments, small and medium business development, jobs creation, expansion of international contacts. Russia has high tourism potential - its territory is a concentration of unique natural and recreational resources, objects of national and world cultural and historical heritage. Besides, Russia often holds important economic, cultural, social and sports events. Many regions are proud with a great number of potentially attractive tourist sites that could be very popular among both Russian and foreign tourists. In this connection, the tourism branding of Russian cities and regions represents a relevant and very demanded activity.

\section{THE NOTION OF TOURISM BRANDING}

The process of tourism destinations branding consists in formation and promotion of a tourist territory's brand, which is "a set of unique qualities, universal human values reflecting the original consumer characteristics of the given territory and community, which are widely known, popular and constantly demanded" [41]. In the frames of this research, it is important to point out that the territory's brand is "a unique emotionally positive image conditioned by natural, historical, industrial, socio-cultural and other features of the territory that have become widely known to the public" [1].

According to D.V. Vizgalov, a specialist in city branding in Russia, the city's brand is "a city's identity systematically expressed in bright and attractive ideas, symbols, values, images and fully reflected in city's image" [2]. American researcher S. Anholt also defines branding as the process of forming the territory's identity: "Branding is the process of creating, planning and promotion of name and identity with the purpose of reputation creation and management" [3]. It should be noted that for quite a long time, the issues of territorial branding were studied, mainly, by economists and marketing experts. Foreign as well as Russian specialists achieved significant results in the study of different aspects of territories' branding, including the role of branding in the formation of the image of a tourist territory [4-18].

Against the background of active scientific search by marketing experts and brand managers, the phenomena of brand and branding have become the research subject of other humanities branches - sociology, philosophy, history, culture. For example, the psychological research by $\mathrm{Yu}$.Yu. Brovkina analyzes the participants of brand communication [19]; O.F. Rusakova and V.M. Rusakov propose carrying out the philosophical analysis of the structure of the discourse of brand and image [20]; N.G. Pryakhin attempts to determine the importance of branding and its social and philosophical aspects [21]; M.A. Kuzmenkova studies the communicative component of territorial branding [22]. Let us note that the linguistic interpretation of the concept of "brand" has not yet received a systematic, integrated implementation. The 
following works are of interest in this aspect: the study of brand discourse with the help of socio-dynamic and pragmatic-stylistic analysis of the brand, reconstructed in the company's texts in social networks [23]; the research of naming as one of branding technologies [24]; the study of brand name as the initial basis for understanding the effectiveness of the name selection for the branding process [25].

\section{METHODOLOGY}

Creation and promotion of a tourist brand of the territory requires the use of various marketing tools, including exhibition events, advertising in mass media, publication of advertising and informational literature, use of the latest electronic technologies (Internet, multimedia discs, e-mail marketing), PR actions, organization of study tours and promotional tours, etc. [26]. The marketing approach to branding, which is currently a dominant one, cannot be effective without linguistic methods of research, since the verbal component still plays a key role in shaping the attractive image of a country, a region or a tourist destination. In this regard, there is a need to study tourism branding from the linguistic viewpoint, as well as to develop the conception of linguistic logistics of territory's branding.

In the conditions of rapid development of tourism sector which stimulates the creation of advertising and informative texts - a powerful tool of the industry - the tourism discourse is of great interest for linguists. The analysis of research literature has shown that Russian linguists have focused their attention on tourism quite recently, and today one may distinguish the following directions of studies:

- $\quad$ pragmatic - studying argumentation techniques and advertising strategies (G.S. Atakyan, O.P. Karebina, S.A. Pogodaeva, H.A. Tyuleneva);

- $\quad$ cognitive - specification and description of concepts and the main set of conceptual metaphors of tourism discourse (T.I. Babkina, Yu.V. Belkova, E.A. Bobrova, E.A. Starodubtseva, E.M. Shevchenko);

- $\quad$ comparative - description of national differences in tourism discourse (M.Yu. Ilyushkina, E.E. Menshikova, L. Tszyuan, V.A. Mityagina).

Several works devoted to the study of typological status and system-forming parameters of tourism discourse are also worth mentioning. S.A. Pogodaeva attempts to define the notion of tourism discourse as a special mass-information and status-oriented institutional discourse, which specificity consists in the field of its use - the sphere of tourism [27]. N.V. Filatova analyzes the prototypical characteristics of tourism discourse in the system of institutional discourse practices and distinguishes the most popular genres in the tourist communication [28]. Researchers note the hybrid nature of tourism discourse and in search for an answer to the question about its typological status; they acknowledge its unconditional connection with the advertising discourse $[29,30]$. One cannot but agree with the conclusions that tourism discourse is a special subtype of advertising discourse, which is characterized by the hybrid nature of the individual components of the macrostructure of discourse's texts. Besides, tourism discourse has the markers of historical and fine-art discourses which together ensure its complex nature [29].

Despite the increasing number of works devoted to tourism discourse, the language and non-language codes, the distinctive linguistic features as well as communicative strategies and tactics used within this type of discourse, still remain insufficiently studied and analyzed. As for the linguistic study of territorial branding, unfortunately, there is only a small number of completed studies, including the work by O.V. Prasolova devoted to the communicative strategies for region's image formation [31]; thesis research by I.A. Sushnenkova which studies the regional brand from the viewpoint of linguistic cognition [32]; monograph by M.V. Terskikh and E.D. Malenova, describing the linguo-conceptual approach to reconstructing the territory's image [33]. The article by A.A. Gureeva is of special practical interest, as it deals with the ways of implementing PR-functions of texts of tourism branding. The researcher notes that "in the pragmatic program of branding texts which explicate the region as a tourist territory, the main role is played by the pragmatics of a recipient as a potential consumer of the tourist product". And she concludes that in the process of tourism branding "it is necessary to take into account the communicative and pragmatic conventions for creating the texts of several types of discourse: tourism, advertising and PR-discourse" [34].

Since the study of linguistic aspects of tourism branding is a relatively new direction, it seems necessary to identify a range of problems and relevant research tasks:

- $\quad$ linguistic interpretation and definition of the concepts of territory's brand and territory's image;

- determining the paradigm of text genres with "branding" potential;

- $\quad$ revealing communicative and pragmatic conventions of branding texts;

- development of criteria for the creation of branding texts;

- determining genre-forming features of certain types of branding texts, etc.

It should be noted that along with the above-mentioned issues, the intercultural and translational aspects are very important for the study of tourism branding. These aspects involve studying the peculiarities of the creation and promotion of tourism territory's brand in a foreign communicative space, comparative studies, as well as the study of translation problems, strategies and technologies. Both theoretical studies and practical developments in this sphere are extremely urgent and demanded, since the development of the tourism industry is one of the relevant directions of social and economic development of Russia and many other countries around the world. Therefore, the formation and promotion of a positive image of cities and regions as attractive tourist destinations is an urgent issue with respect to both "domestic" and foreign tourists. 
In the authors' opinion, it is important to realize that "a favorable image of the so-called strange, foreign country and propriety of the undertaken marketing strategies to make regions attractive for tourists depend on successful communication within intercultural tourist discourse. "Tourism discourse is multifunctional and suspects manysided research paradigms considering diverse genre peculiarity and the role which tourism plays in the modern society" [35]. However, the analysis of existing research has shown, that at the moment there are few studies considering the tourism discourse and tourism branding from the intercultural or translational viewpoint. The authors' focused our attention on several works by Russian and foreign linguists and translators. For example, A.A. Novozhilova determines discoursedependent translation strategies when working with tourism texts [36]; the article by I.D. Romadina and V.A. Mityagina deals with the problem of translation and localization of microtoponyms, which are the names of human-created objects of geographical space such as squares, parks, museums, theaters, avenues within the online tourism discourse [37]. The relevant issues also include the translation of names of culture-bound items ('realia') which perform important functions in the tourism discourse [38,39], expression of discourse and genre strategies of communicators [40,41], communicative, pragmatic and semantic aspects of translating tourism texts [42], etc.

A number of works touches upon the didactic aspect of translating tourism texts. The study by A.A. Novozhilova, devoted to the translational and didactic aspects of the tourism discourse, proposes training for the development of translation competences and translation strategies typical for tourism texts' translation [43]. Using the example of students' translations, D. Stewart studies the problems faced by starting translators when working with texts of tourism discourse [44]. H.-J. Bopst notes the rapidly growing role of tourism in modern society and the world economy and proposes to include tourism texts in the process of teaching foreign languages and translation, in particular, as the objects of editing [45].

As it was mentioned above, the formation of a tourism brand involves using various technologies, creating and applying verbal and visual symbols. The brand of the territory is an indicator of its recognizability, a tool for its presentation on the regional, country, or even world level. The purpose of territorial branding consists in ensuring the presence of the territory's brand in the informational space, the possibility of its recognition, ensuring the influence of the branded territory, the inflow of financial resources, broadcasting events outside the territory [46]. The development of tourism, the transformation of territories into an attractive place for visitors are the tasks of territorial branding.

\section{RESULTS}

The key element of the branding conception is represented by the creation of a brand name, as well as its attributes, i.e. identification symbols, for example, a logo, a slogan, etc. That is why studying the brand name is the initial basis for understanding the effectiveness of choosing a name for the branding process. Creating a brand of a tourist territory (country, region, city) is always based on their uniqueness historical, natural, architectural identity, scientific and cultural achievements, that are often reflected in the brand name. So, what is the communicative and pragmatic role of the brand name in tourism texts, the texts of tourism branding? How does it change in the text of translation? Let us carry out the analysis of the nominative adequacy of the process of translating the name of tourism brand.

Interkon Travel Service GmbH / Levitin Reisen company, one of the largest and most famous Russian-language tour operators in Germany, is focused on both inbound and outbound tourism and successfully organizes excursion tours around Germany and various countries of Europe and the whole world. The company's website offers its readership the texts in Russian and in German (http://www.levitin.de) that seems logical and effective for the maximum comfort of potential travelers, since their language skills and personal characteristics may be different. Let us analyze the Russianlanguage and German-language texts describing the tour to the second largest city of Russia - Saint Petersburg.

The very name of the tour in Russian and in German reflects the text's pragmatics (Table 1) - the company as the addresser of the text takes into account different expectations of Russian-speaking and German-speaking participants of the tour. The emphasis on the imperial history of St. Petersburg in the Russian-language version is obvious because Russianspeaking tourists know the city as the cradle of the revolution, the city of V.I. Lenin, and in the German-language version, the focus is made on the "introductory" nature of the tour (the city is to be discovered - entdecken):

TABLE 1. NAMES OF THE TOUR IN RUSSIAN AND IN GERMAN TEXTS

\begin{tabular}{|l|l|}
\hline \multicolumn{1}{|c|}{ Russian-language version } & \multicolumn{1}{|c|}{ German-language version } \\
\hline $\begin{array}{l}\text { "Столица Pоссийской империи» } \\
\text { (Cарital of Russian Empire) }\end{array}$ & $\begin{array}{l}\text { Sankt Petersburg entdecken ... } \\
\text { (Getting acquainted with St. } \\
\text { Petersburg) }\end{array}$ \\
\hline
\end{tabular}

This socio-communicative parameter is traced further in the description of the tour program; in particular, one can observe the phenomenon of localization in the form of compression in the analyzed texts. The example given in Table 2 shows the difference between the functions of the city brand in Russian and German texts. In the Russian text, the brand names of St. Petersburg - Great city, Northern capital, one of the six most beautiful cities of Europe - reflect the new trends of tourism discourse, which, in this case, manifests its hybrid, synthetic character and realizes the features of the advertising discourse. This is due to the Internet acting as a multiplying interactive space which successfully and effectively multiplies the informational and communicative potential of the texts. It should be noted that these additional characteristics of the main brand cannot be explicated to a full pragmatic and axiological extent in the German text. A city of global historical and cultural significance (for example, Rome, Jerusalem, Paris, etc.) may be referred to under the adjective Great in the European consciousness. As for the wordcombination Northern capital, it is associated with St. Petersburg only by those who know well the history of Russia. 
The Russian-speaking people, on the other hand, do not associate the city with the names Northern Venice and Northern Palmyra.

TABLE 2. BRAND NAMES OF ST. PETERSBURG IN RUSSIAN AND IN GERMAN TEXTS

\begin{tabular}{|c|c|}
\hline Russian-language version & German-language version \\
\hline 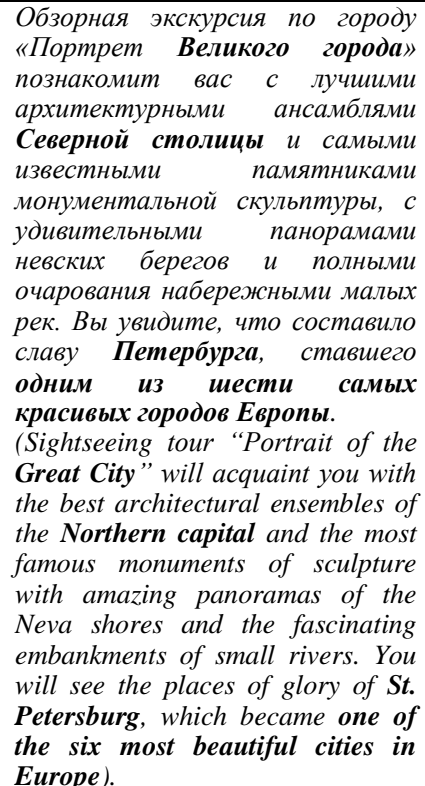 & $\begin{array}{l}\text { Stadtrundfahrt mit den wichtigsten } \\
\text { Sehenswürdigkeiten. } \\
\text { (Sightseeing tour to the most famous } \\
\text { destinations). }\end{array}$ \\
\hline
\end{tabular}

The museum brands (Table 3) of the Peter and Paul Fortress and the Peter and Paul Cathedral cannot manifest their key values - creative curiosity, openness, education and enjoyment - in the text for German-speaking recipients. Information is reduced to a minimum, but there is an addition, which is important for understanding the significance of the cathedral: Begräbniskirche aller Zaren (the tomb of all kings). This denotative component of the brand name completely compensates for the non-expressed information in the text about the history of city's birth; a unique cathedral, the gilded spire of which overlooks the city. Certainly, the designation of the cathedral as the tomb of all kings is an actual mistake, which could have been easily avoided by using the word combination all Russian emperors (aller russischen Kaiser) instead of all kings.

The German-language fragment about the excursion to the Hermitage (Table 4), another brand of St. Petersburg, contains addition in the form of specifying information: mit fast drei Millionen Exponaten (numbering almost three million exhibits), which is absent in the Russian-language text. Such accurate information is always of interest to German tourists. Besides, the indication that the Hermitage is the most significant art museum in Russia (das bedeutendste Kunstmuseum Russlands) is also specifically oriented to German-speaking tourists and it would be redundant in the Russian text. In this case, one can say that the authors of these texts tried to take into account the pragmatic characteristics of a foreign recipient.
TABle 3. The museum BRANDS (TABle 3) OF the Peter ANd PAUl ForTRESS AND THE PETER AND PAUl CATHEDRAL IN RUSSIAN AND IN GERMAN TEXTS

\begin{tabular}{|c|c|}
\hline Russian-language version & German-language version \\
\hline 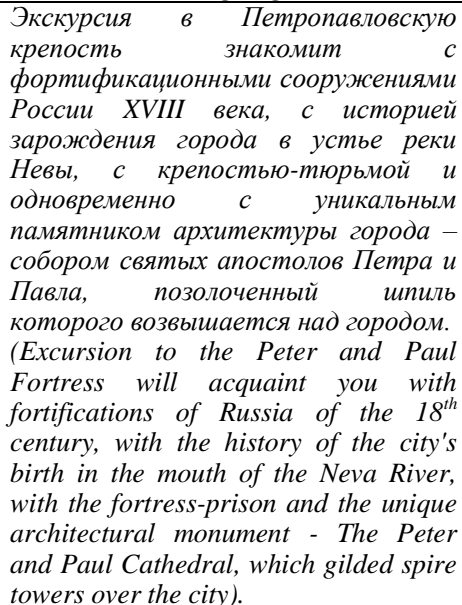 & $\begin{array}{l}\text { Besichtigung des Territoriums } \\
\text { der Peter-Paul-Festung mit der } \\
\text { Peter-Paul-Kathedrale, } \\
\text { Begräbniskirche aller Zaren. } \\
\text { (Excursion to the Peter and Paul } \\
\text { Fortress and the Peter and Paul } \\
\text { Cathedral - a mausoleum of } \\
\text { Russian emperors). }\end{array}$ \\
\hline
\end{tabular}

TABLE 4. FRAGMENT ABOUT THE EXCURSION TO THE HERMitAGE MUSEUM IN RUSSIAN AND IN GERMAN TEXTS

\begin{tabular}{|c|c|}
\hline Russian-language version & German-language version \\
\hline 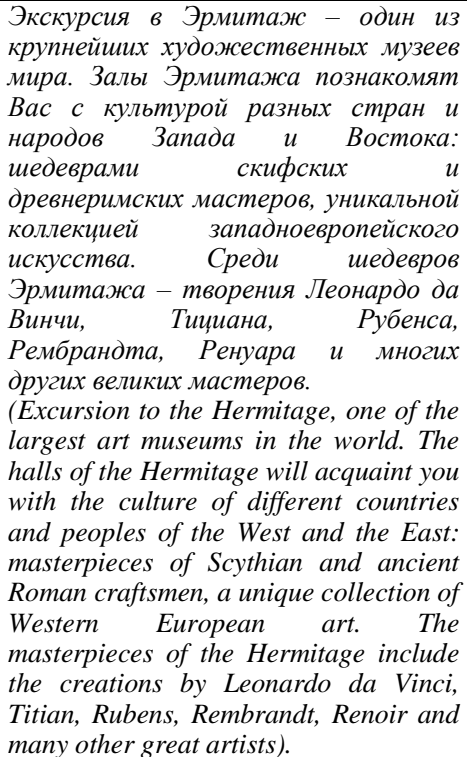 & $\begin{array}{l}\text { Besichtigung des Ermitage- } \\
\text { Museums, das mit fast drei } \\
\text { Millionen Exponaten das } \\
\text { bedeutendste Kunstmuseum } \\
\text { Russlands und zugleich auch } \\
\text { eines der bedeutendsten der } \\
\text { Welt ist } \\
\text { (Excursion to the Hermitage, the } \\
\text { most important art museum of } \\
\text { Russia and the world, with } \\
\text { collection of about 3mln } \\
\text { exhibits). }\end{array}$ \\
\hline
\end{tabular}

Such localization in the form of compression (the Germanlanguage texts are in fact three times shorter than the texts in Russian) is observed almost in all the texts of this website, since the focus of the tour operator, primarily, on the Russianspeaking customer, determined the minimalist strategy for creating the text in German - the strategy of expressing only the general information.

Let us compare the nominations of brands of Volgograd (Table 5 and Table 6), proposed in the texts of the fourlanguage Internet portal of tourism - Volgocity: Official city guide - created by academic staff and students of the Department of translation theory and practice of Volgograd State University (http://volga-land.volsu.ru/ru). 
TABle 5. Volgocity: OFFICIAL CITY GUIDE. TEXT 1

\begin{tabular}{|c|c|}
\hline Russian-language version & German-language version \\
\hline $\begin{array}{l}\text { Уникальный для России и Европьы } \\
\text { историко-архитектурный } \\
\text { комплекс Сарепть создал особый } \\
\text { микроклимат культурно-бытовой } \\
\text { среды немецких переселенцев. } \\
\text { (The historical and architectural } \\
\text { complex of Sarepta, unique for Russia } \\
\text { and Europe, created a special } \\
\text { microclimate of the cultural and } \\
\text { domestic environment of German } \\
\text { immigrants). }\end{array}$ & $\begin{array}{l}\text { Das einmalige Museum „Alt- } \\
\text { Sarepta“ bewahrt kostbare } \\
\text { Objekte der deutschen } \\
\text { Herrnhuter-Kolonisten aus dem } \\
\text { 19. Jhdt und gehört zum } \\
\text { historisch-kulturellen } \\
\text { Russlands und Europas. } \\
\text { (The unique museum Old Sarepta } \\
\text { preserves valuable objects of } \\
\text { German Hernguters-Colonists of } \\
\text { the 19th century and represents a } \\
\text { historical and cultural legacy of } \\
\text { Russia and Europe). }\end{array}$ \\
\hline
\end{tabular}

TABLE 6. VOLGOCITY: OFFICIAL CITY GUIDE. TEXT 2

\begin{tabular}{|c|c|}
\hline Russian-language version & German-language version \\
\hline 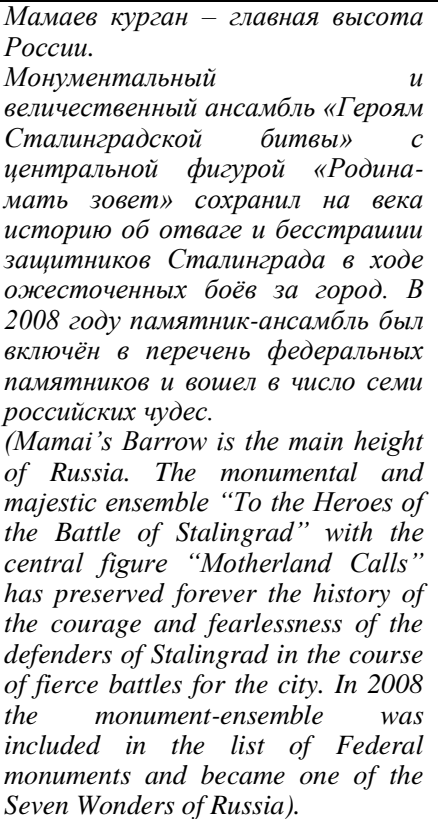 & $\begin{array}{l}\text { Mit dem Mamajew Kurgan } \\
\text { entstand auf einem Hügel eines der } \\
\text { größten Kriegsdenkmäler der Welt, } \\
\text { das seit } 2008 \text { zu den Sieben } \\
\text { Wundern Russlands zählt. Die } \\
\text { Gedenkstätte, gekrönt von der } \\
\text { Riesenfigur der, ,Mutter Heimat", } \\
\text { ist den sowjetischen Soldaten sowie } \\
\text { den tapferen Zivilisten, Partisanen } \\
\text { und Müttern gewidmet. } \\
\text { "Motherland Calls", one of the } \\
\text { largest memorials of the world was } \\
\text { created on the Mamai's Barrow. } \\
\text { This sculpture, which since 2008 } \\
\text { has been one of the Seven Wonders } \\
\text { of Russia, is dedicated to Soviet } \\
\text { soldiers, courageous citizens, } \\
\text { partisans and mothers). }\end{array}$ \\
\hline
\end{tabular}

Let us note the nominative characteristics explicated in the text of translation and significant for the brand. In this case, there is the maximum "re-expression" of the original phrase, made taking into account the pragmatics of text creation for the German-speaking recipient. Special attention should be paid to the increased degree of differentiation: German immigrants are narrowed to deutsche Herrnhuter-Kolonisten (German Hernguters- colonists), that is important for the presentation of the museum to a potential tourist. The text about the Mamaev Kurgan (Mamai's Hill) ensemble contains additional information - eines der größten Kriegsdenkmäler der Welt (one of the largest military monuments in the world), which is also important for a German-speaking tourist.

\section{CONCLUSION}

Thus, the authors can state that the nominations of the tourist brand in translated texts can be, on the one hand, simplified and reduced, and, on the other hand, expanded to a significant scale for potential tourists. These processes of narrowing and expanding nominations are conditioned by the pragmatics of communicative interactions in the tourism discourse, which determine the necessary degree of explicitation and the form of pointing out separate components of the semantic-pragmatic content of the brand.

Summarizing the aforesaid, it is necessary to outline the tasks, the solution of which is relevant and necessary for studying the specificity of tourism branding in the translational aspect:

- identifying the pragmatic specificity of a foreignlanguage recipient of branding texts;

- finding the optimal technology for translating the tourism branding texts;

- pragmatically adequate translation of the tourist brand's name;

- $\quad$ studying regionally specific translation problems of onomastic nomination;

- $\quad$ linguistic and cultural adaptation of branding texts in the process of translation, etc.

In the authors' opinion, the study of these issues contributes to the development of the conception of effective linguistic logistics of tourism branding, which includes the creation of the brand of a tourist territory and ensuring its functioning in Russian and other foreign languages.

\section{Acknowledgment}

The reported study was funded by RFBR and Government of the Volgograd region according to research project № 17 14-34001 "Regional tourism as a factor of discourse and translation technology formation: nominative and communicative-pragmatic conventions of text as a branding tool" (Regional contest "Volga lands in the history and culture of Russia" 2017 - Volgograd region).

\section{References}

[1] I.S. Vazhenina, Image, reputation and brand territory, Ekaterinburg: Institute of Economics, UrB RAS, 2013. 378 p. (in Russian).

[2] D.V. Vizgalov, City Branding, Moscow: Institute of Urban Economics Fund, 2011. 160 p. (in Russian)

[3] S. Anholt, Branding: the road to the global market, Moscow: KuditsObraz, 2004. 272 p.

[4] S. Anholt, "Editorial: Definitions of place branding - Working towards a resolution," Place branding and public diplomacy, vol. 6, no. 1, pp. 1-10, 2010

[5] S. Anholt, "Editorial: place branding: is it marketing, or not?" Place branding and public diplomacy, vol. 4, no. 1, pp. 1-6, 2008

[6] S. Anholt, Places: Identity, Image and Reputation, New York: Palgrave MacMillan, 2009. 256 p.

[7] V.-A. Briciu, "Differences between place branding and destination branding for local brand strategy development," Bulletin of the Transilvania University of Braşov. Series VII: Social Sciences, Law, vol. 6 (55), no. 1, 2013.

[8] J. Clarke, "Tourism brands: An exploratory study of the brands box model," Journal of Vacation Marketing, vol. 6, no. 4, pp. 329-345, 2000.

[9] A.M. Goglenkov, "Branding of tourist destinations as a direction of territorial branding," Humanitarian scientific research, No. 7, part 2, 
2015 ,

[Electronic http://human.snauka.ru/2015/07/11867.

[10] R. Govers and F. Go, Place Branding: Glocal, Virtual and Physical Identities, Constructed, Imagined and Experienced, Great Britain: Palgrave Macmillan, 2009. $325 \mathrm{p}$.

[11] I.V. Groshev and Yu.V. Shapkina, "Use of information and analytical technologies in the branding of the territory of innovative development," [Ispolzovanie informatsionno-analiticheskikh tekhnologiy $\mathrm{v}$ brendinge territorii innovatsionnogo razvitiya] in News of Tomsk Polytechnic University. Engineering of georesources, vol. 324, no. 6, pp. 57-64, 2014.

[12] M. Hall, "Tourism Destination Branding and its Affects on the National Branding Strategies: Brand New, Clean and Green But is it Smart?" [Electronic resource]. URL: http://www.academia.edu/416648/.

[13] N.V. Levochkina, "Tourist brands of the territory: structure and features," [Turisticheskie brendy territorii: struktura i osobennosti] in: Russian Entrepreneurship, No. 20, pp. 152-158, 2012.

[14] N.P. Shalygina, M.V. Selyukov and E.V. Kurach, "On the role of branding in forming the tourist attractiveness of the region," [O roli brendinga $\mathrm{v}$ formirovanii turistskoy privlekatel'nosti regiona] in: Fundamental Research, No. 8-5, pp. 1165-1168, 2013.

[15] I.S. Vazhenina, "Image and brand of the region: essence and features of formation," Economy of the region, No. 1, pp. 49-58, 2008. (in Russian)

[16] I.S. Vazhenina, "On the essence of the brand territory," Economy of the region, No. 3, pp. 18-23, 2011. (in Russian)

[17] I.V. Voronkova, "Innovative approaches in territorial branding," Bulletin of Orel GIET, No. 2 (32), pp. 139-141, 2015. (in Russian).

[18] G.V. Vorontsova, "Theoretical-methodological approaches to branding of territory," Bulletin of the North-Caucasian University, No. 3 (32), pp. 217-221, 2012. (in Russian).

[19] Yu.Yu. Brovkina, "Social psychology of brand communication: Dr. psychol. sci. dis.," Moscow, 2009. 443 p. (in Russian).

[20] O.F. Rusakova and V.M. Rusakov, "PR-discourse: theoretical and methodological analysis". Ekaterinburg: UrB RAS, Discourse-Pi, 2011. $336 \mathrm{p}$.

[21] N.G. Pryakhin, "Socio-philosophical aspects of branding," Branding as communicative technology of the $21^{\text {st }}$ century: Proceedings of the III All-Russian Scientific and Practical Conference, March 1-3, 2017, A.D. Krivonosov, Ed. Saint Petersburg, Publishing house SPbGEU, 2017, pp. 27-30. (in Russian).

[22] M.A. Kuzmenkova, "Communicative component of territorial branding (on the example of Moscow and Moscow region)," Mediascope, 2016, vol. 4 [Electronic resource]. URL: http://www.mediascope.ru/node/2184. (in Russian).

[23] I.P. Romashova, "Linguistic analysis of brand communication," Scientific dialogue, No. 6 (54), pp. 80-93, 2016. (in Russian).

[24] L.V. Balakhonskaya, "The main stages of naming Branding as communicative technology of the $21^{\text {st }}$ century: proceedings of the II AllRussian Scientific and Practical Conference with International Participation, February 25-26, 2016, A.D. Krivonosov, Ed. Saint Petersburg, Publishing House of SPbGEU, 2016. pp. 158-160. (in Russian).

[25] L.V. Ukhova, "Communicative possibilities of the commercial name," Branding as communicative technology of the $21^{\text {st }}$ century: Proceedings of the III All-Russian Scientific and Practical Conference, March 1-3, 2017, A.D. Krivonosov, Ed. St. Petersburg: Publishing house SPbGEU, 2016, pp. 171-174. (in Russian).

[26] S.V. Volkov, "Marketing promotion of Russia as a tourist destination: monograph," Volgograd, 2016. 128 p. (in Russian).

[27] S.A. Pogodaeva, "Linguistic means of argumentation in the French tourism discourse: Cand. philol. sci. dis.," Irkutsk, 2008. 234 p. (in Russian).

[28] N.V. Filatova, "Genre space of tourism discourse," Bulletin of Moscow State University named after M.A. Sholokhov. Series "Philological Sciences", 2012, no. 2, pp. 76-82. (in Russian).

[29] N.V. Filatova, "Tourism discourse in pragmatic and linguistic aspects: Cand. philol. sci. dis.," Moscow, 2014. 179 p. (in Russian).
[30] N.A. Tyuleneva, "Linguo-cognitive strategy of positioning and promotion of tourist services in Russian and Anglo-American advertising: Cand. philol. sci. dis.," Omsk, 2008. 269 p. (in Russian).

[31] O.V. Prasolova, "Formation of the region's image in the mass media: on the example of the Khanty-Mansiysk Autonomous District of Ugra: Cand. philol. sci. dis.," Voronezh, 2010. 165 p. (in Russian).

[32] I.A. Sushnenkova, "Linguo-cognitive study of regional image: Cand. philol. sci. dis.," Omsk, 2011.272 p. (in Russian).

[33] M.V. Terskikh and E.D. Malenova, "Media image of the Siberian region: linguo-cognitive modeling: monograph," Omsk: LITERA, 2015. 160 p. (in Russian).

[34] A.A. Gureeva, "PR-function of the text of tourism branding: linguistic means as a way of realization," Branding as communicative technology of the $21^{\text {st }}$ century: materials of the $3^{\text {rd }}$ All-Russian Scientific and Practical Conference, 1-3 March 2017, SPbGEU, St. Petersburg. Yaroslavl; St. Petersburg: Publishing house SPbGEU, 2017, pp. 128132. (in Russian).

[35] A.A. Gureeva, E.Yu. Novikova and V.A. Mityagina, "Guideinterpreter's language identity as an excursion discourse factor," in: XLinguae Journal, vol. 9, iss. 2, pp. 90-102, 2016.

[36] A.N. Novozhilova, "Strategies for translating texts of tourism discourse (on the materials of the hotel site)," Contemporary studies of social problems (electronic journal), No. 8 (52), pp. 138-149, 2015. (in Russian).

[37] I.D. Romadina and V.A. Mityagina, "Translation and localization of microtoponyms (based on Russian and English-language texts of online tourism discourse)," XLinguae Journal, 2017, vol. 10, iss. 2, pp. 112124.

[38] M. Agorni, "Tourism communication: the translator's responsibility in the translation of the cultural difference," Pasos: Revista de turismo y patrimonio cultural, vol. 10, no. 4, pp. 5-11, 2012.

[39] M. Petillo, "Translating cultural references in tourism discourse: the case of the Apulian region," in: Altre Modernita, 2012, pp. 248-263

[40] D. Kelly, "The translation of texts from the tourist sector: textual conventions, cultural distance and other constraints," TRANS: revista de traductología, No. 2, p. 33-42, 1998.

[41] E.A. Zimina, "Problems of translating the texts of the tourism Internet discourse," Translation in a Changing World: Materials of the International Scientific and Practical Conference. Saransk: Azbukovnik Publishing Center, 2015, pp. 200-204. (in Russian).

[42] L. Ivanova, "Texte in der Tourismusbranche - Übersetzungsprobleme," in: Translation in Theorie and Praxis, V. Kučiš, Hrsg. Frankfurt a.M.: Peter Lang, 2013, pp. 163-174.

[43] A.N. Novozhilova, "Translatological and didactic aspects of the texts of tourism discourse," Homo Loquens: (Questions of linguistics and translatology): Collected articles. Iss. 9. Volgograd: Publishing house of VolSU, 2016, pp. 42-53. (in Russian).

[44] D. Stewart, Translating Tourist Texts from Italian to English as a Foreign Language, Liguori Editori, 2012. 144 p.

[45] H.-J. Bopst, "Tourismus - ein neuer Schwerpunkt in Deutschunterricht, Germanistikstudium und Übersetzerausbildung," in: Beiträge der XV. Internationalen Tagung der Deutschlehrerinnen und Deutschlehrer Bozen, 29. Juli-3. August 2013. Band 3.2 - Sektionen E5, E8. Kultur, Literatur, Landeskunde. Bozen: Bozen-Bolzano University Press, 2015, pp. $145-163$.

[46] I.V. Groshev and E.V. Stepanicheva, "Tools for territory's branding," Marketing in Russia and abroad, No. 5, pp. 54-64. 2011 . (in Russian).

\section{Sources}

[1] Website of the German tour operator Interkon Travel Service GmbH / Levitin Reisen (in Russian and German languages) [Electronic resource]. URL: http://www.levitin.de.

[2] Multilingual tourism Internet portal of Volgograd and the Volgograd region "Volgocity: Official city guide" [Electronic resource]. URL: http://volga-land.volsu.ru. 